\title{
Examining muscles of Cirrhinus mrigala for biochemical parameters as a bio-indicator of water pollution by municipal and industrial effluents into River Ravi, Pakistan
}

\author{
Hafiz Abdullah Shakir · Javed Iqbal Qazi • \\ Abdul Shakoor Chaudhry
}

Received: 19 June 2014 / Accepted: 10 October 2014/Published online: 25 October 2014

(C) The Author(s) 2014. This article is published with open access at Springerlink.com

\begin{abstract}
We examined the muscles from replicated samples of Cirrhinus mrigala as a bio-indicator of water pollution following sewage and industrial discharges from the Lahore city into Ravi River of Pakistan. For this, C. mrigala was netted from three variably polluted downstream sites (B, C and D) and one less polluted upstream site (A). The fish was sampled during low (winter) and high (post monsoon) river flow seasons. The fish muscles from site D showed $28 \%$ less total carbohydrates than the fish caught from site A. The muscle carbohydrate contents were further decreased at sites B and C by 58 and $59 \%$ and 77 and $74 \%$, during low and high flows, respectively. Moreover, total lipids, cholesterol and RNA contents for the muscle of the fish from the downstream locations were also decreased up to 29,68 and $58 \%$, respectively. Conversely, total protein, soluble protein and DNA contents were increased in fish muscles progressively downstream during both the low- and high-flow seasons. It appeared that the fish muscle components can change with the level of water pollution which may affect the fish attributes as a safe food.
\end{abstract}

Keywords Aquatic toxicity $\cdot$ Muscle biochemistry $\cdot$ Bio-indicator $\cdot$ Carp

\section{Introduction}

Ravi River is perceived to be one of the most polluted rivers in Pakistan. There are over seven municipal sewage outlets and two drains which discharge their untreated effluents when the river passes through Lahore, the capital of the Punjab province of Pakistan (Saeed and Bahzad 2006; Shakir et al. 2013). Freshwaters such as the Ravi River are highly vulnerable to different sorts of pollutions, since they act as immediate sinks for the outputs of anthropogenic activities. Fishes are one of the richest sources of an essentially healthy diet. Therefore, it is important to know the impacts of water pollution on the health and growth of these animals. Indeed, different changes in aquatic medium can cause several physiological and compositional changes in fish. Industrial and municipal effluents are the main culprits for undesirable

H. A. Shakir · J. I. Qazi ( $\square)$

Department of Zoology, University of the Punjab, Lahore 54590, Pakistan

e-mail: qazi.zool@pu.edu.pk

H. A. Shakir

e-mail: hashakir@yahoo.com

A. S. Chaudhry

School of Agriculture, Food and Rural Development, Newcastle University,

Newcastle upon Tyne NE1 7RU, UK

e-mail: abdul.chaudhry@ncl.ac.uk 
changes in the quality of water and its inhabiting fish (Wilson and Taylor 1993; Shakir et al. 2013). Alterations in biochemical composition of muscles in response to exposure to numerous pollutants have been reported by researchers (Bhathar et al. 2004; Yousafzai and Shakoori 2009). Biochemical profiles are commonly used as stress indicators because most biochemical defenses respond to cellular injury through self-regulating signal transduction mechanisms (Safahieh et al. 2010). Investigation of biochemical parameters can be helpful in identifying target organs of toxicity as well as general health status of animals because it has been advocated for presenting early warning of potentially damaging changes in stressed organisms (Jacobson-Kram and Keller 2001).

The aim of this study was to examine the fish muscles as a bio-indicator of potential impact of water pollution on the biochemical features of $C$. mrigala representing one upstream (less polluted as a reference or A) and three downstream (polluted as B, C and D) sites of the Ravi River. The fish species such as C. mrigala is one of the major fresh water carps native to Pakistan and other Asian countries. This fish is known for their high nutritive value, good taste, great price and huge demand in the market.

\section{Materials and methods}

Study sites and fish sampling

Fish specimen C. mrigala (mori) was collected from four sampling sites (A siphon, B Shahdara, C Sunder, D Balloki) of the Ravi River (Fig. 1) during low (winter months of Nov-Dec 2009) and high (post monsoon months of Sep-Oct 2010) flow seasons. Details of fish sampling and sites have been described previously (Shakir et al. 2013; Shakir and Qazi 2013). Nine fish specimens representing each sampling site of similar sizes were collected from three nets per site. The fish was immediately killed, washed with water, drained, and transferred to individually labeled polythene bags which were immediately transported in ice boxes to the laboratory. Biometric measurements of these fishes were recorded as described by Shakir and Qazi (2013). Each fish sample was then dissected to collect muscles which were stored in individually labeled sterilized polythene bags at $-20{ }^{\circ} \mathrm{C}$ until further analysis.

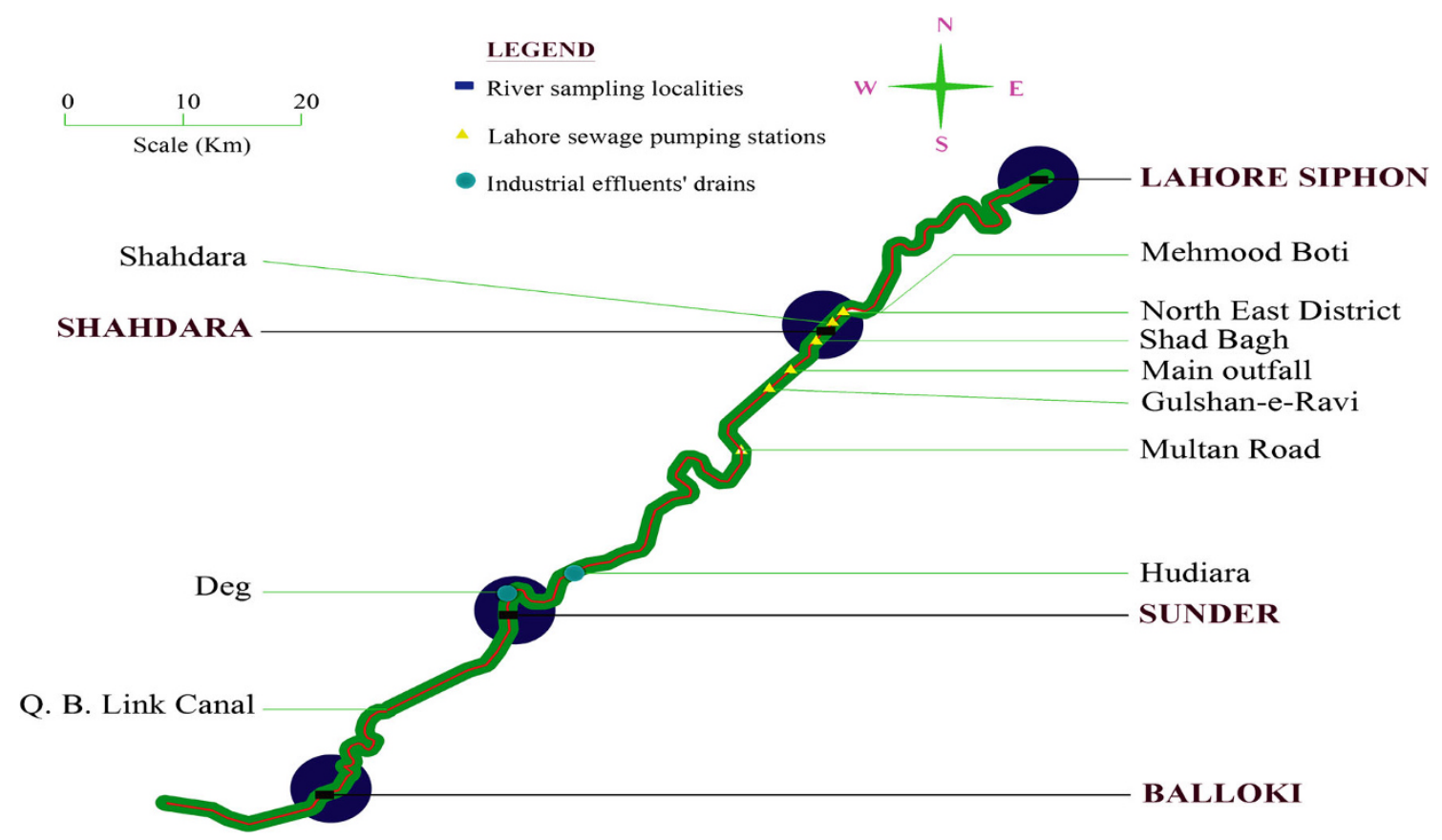

Fig. 1 Map of the Ravi River Lahore showing the four sampling sites around major urban pollution inlets of Lahore (Shakir et al. 2013) 
Biochemical analysis of the fish muscles

The frozen fish muscles were processed to obtain their extracts in ice-cold saline as described by Anwar et al. (2004). In brief, the fish muscles were cut into small pieces with a clean razor, thawed with distilled water and blotted with adsorbent paper. Then, $1 \mathrm{~g}$ muscle of a fish was homogenized in $4 \mathrm{ml}$ ice-cold saline $(0.89 \%$ $\mathrm{NaCl}$ ) with the help of a motor-driven homogenizer. The homogenate was centrifuged at 4,900 rpm for $45 \mathrm{~min}$ at $5{ }^{\circ} \mathrm{C}$ in a refrigerated centrifuge and the supernatant was separated for the determination of total carbohydrates by the method of Du Bios et al. (1956) and soluble protein as described by Lowry et al. (1951). For the estimation of total protein by the method of Lowry et al. (1951), $0.5 \mathrm{~g}$ of a frozen muscle was processed as described before but homogenized in $4 \mathrm{ml}$ ice-cold $0.5 \mathrm{~N} \mathrm{NaOH}$.

For the estimation of nucleic acid contents, $0.5 \mathrm{~g}$ of a fish muscle was boiled in $3 \mathrm{ml}$ ethanol in caped test tubes immersed in a boiling water bath at $90{ }^{\circ} \mathrm{C}$ for $1 \mathrm{~h}$. The contents in the test tubes were then incubated overnight at $37^{\circ} \mathrm{C}$. The homogenates were later centrifuged at 2,000 rpm for $10 \mathrm{~min}$ to get a clear ethanol supernatant. The pellets were used for nucleic acid extraction, while the ethanol supernatant was decanted into glass vials and evaporated at $70{ }^{\circ} \mathrm{C}$ in oven. The yellowish dried residue containing lipid and cholesterol components was then dissolved in $0.5 \mathrm{ml}$ of chloroform and used for the analysis of total lipids as described by Henry and Henry (1974) and cholesterol as described by Henry (1964). Pellets were processed for the extraction of nucleic acids as adopted by Shakoori and Ahmed (1973). DNA and RNA contents were estimated according to Schneider (1957).

Statistical analysis

The data were statistically analyzed using Minitab software to find the effect of sites, seasons and site $\times$ season on the biochemical parameters of fish muscles for either very high significance at $P<0.001$ or high significance at $P<0.01$ or significance at $P<0.05$. Turkey test was used if there were more than two means to compare for significant difference at $P<0.05$.

\section{Results}

Mean values of biometric measurements (total length, wet weight) and various biochemical parameters of muscles of the fish sampled from four sites of Ravi River during both the flow seasons are presented in Table 1. The biometric data did not differ significantly $(P>0.05)$ for sites, seasons and sites $\times$ seasons interaction. However, all the biochemical parameters showed significant differences between seasons and among downstream sites, except the DNA content $(P<0.05)$. The entire biochemical parameters showed non-significant site $\times$ season interactions $(P>0.05)$.

The biochemical parameters appeared to be changing in response to the perceived pollution levels of the downstream sites. Here, total and soluble proteins and DNA contents of the muscles showed increases while carbohydrate, total lipids, cholesterol and RNA contents decreased for up to site C during both lowand high-flow seasons. These changes in the biochemical parameters tended to stabilize at site D and rather showed a recovery as compared to the values obtained for the site $\mathrm{C}$ (Table 1). The mean total protein contents of the fish muscles increased for up to 56, 105, 62 \%, while soluble proteins showed elevations of 37,106 and $78 \%$ for the sites B, C and D, respectively, over the corresponding values for the site A when the data were averaged over the low- and high-flow seasons. The increases in protein contents of muscles sampled from the three downstream locations were comparable during both low- and high-flow seasons. While vivid differences appeared for the DNA content, which increased for up to $2.8,6.2$ and $3.5 \%$ at sites $\mathrm{B}, \mathrm{C}$ and $\mathrm{D}$, respectively, during high flow but could show elevation of $2 \%$ at site B but decrease of $2.7 \%$ at site $\mathrm{C}$ during low-flow season compared to the relevant values at site $\mathrm{A}$ in respective seasons (Fig. 2).

Carbohydrates, total lipids, cholesterol and RNA showed variable decreases for the muscles sampled from the downstream sites as compared to their respective values obtained at the upstream site A. The decreases, in general, appeared to be intensified during low-flow season (Fig. 2). Reductions in muscle carbohydrate ranged from 28 to $77 \%$ and from 29 to $74 \%$, total lipids from 10.8 to $28.9 \%$ and from 12.9 to $27.4 \%$, cholesterol 


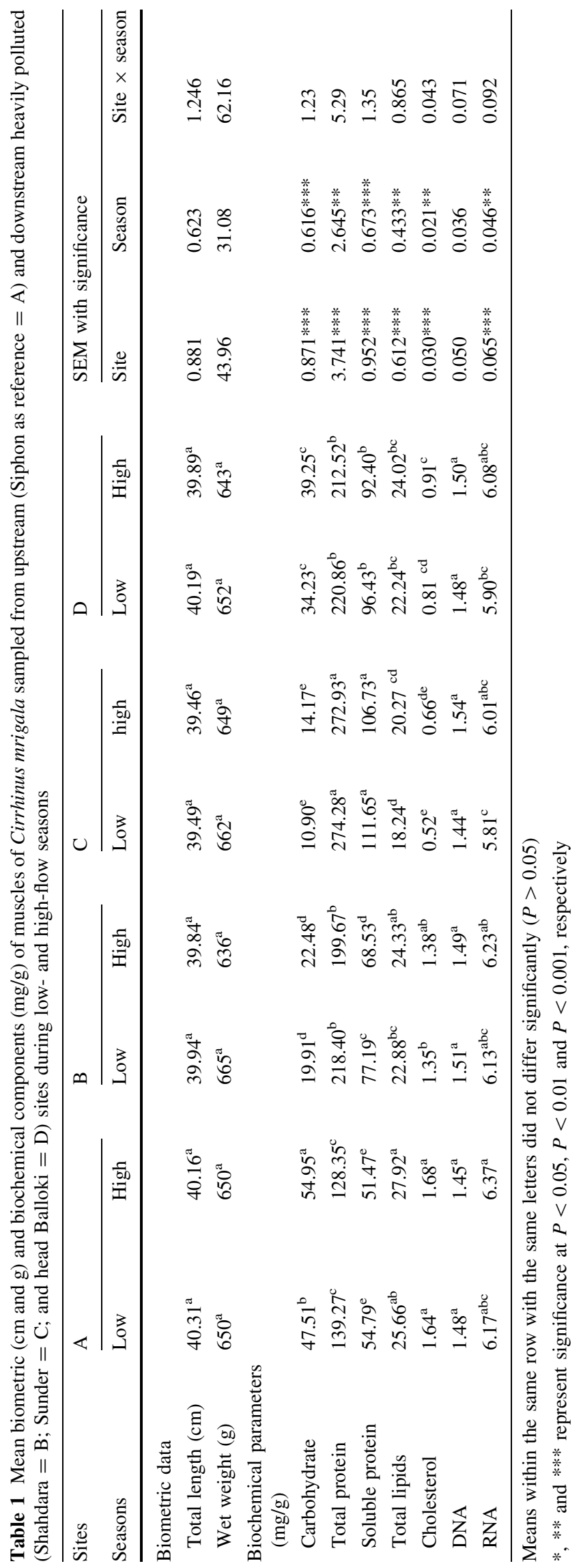



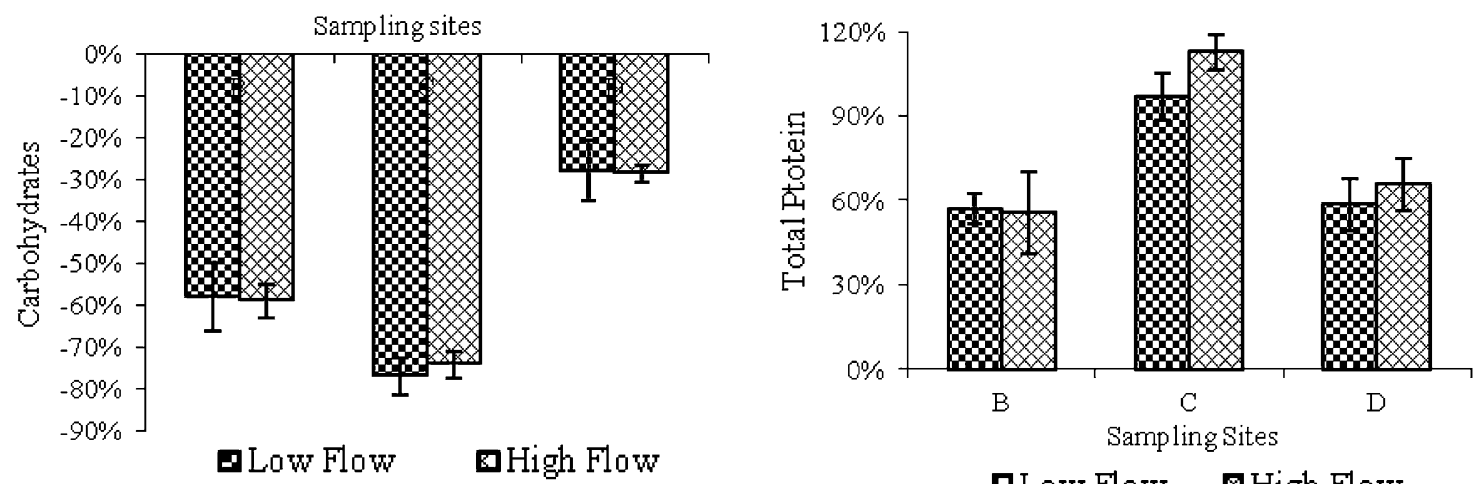

DLow Flow UHigh Flow
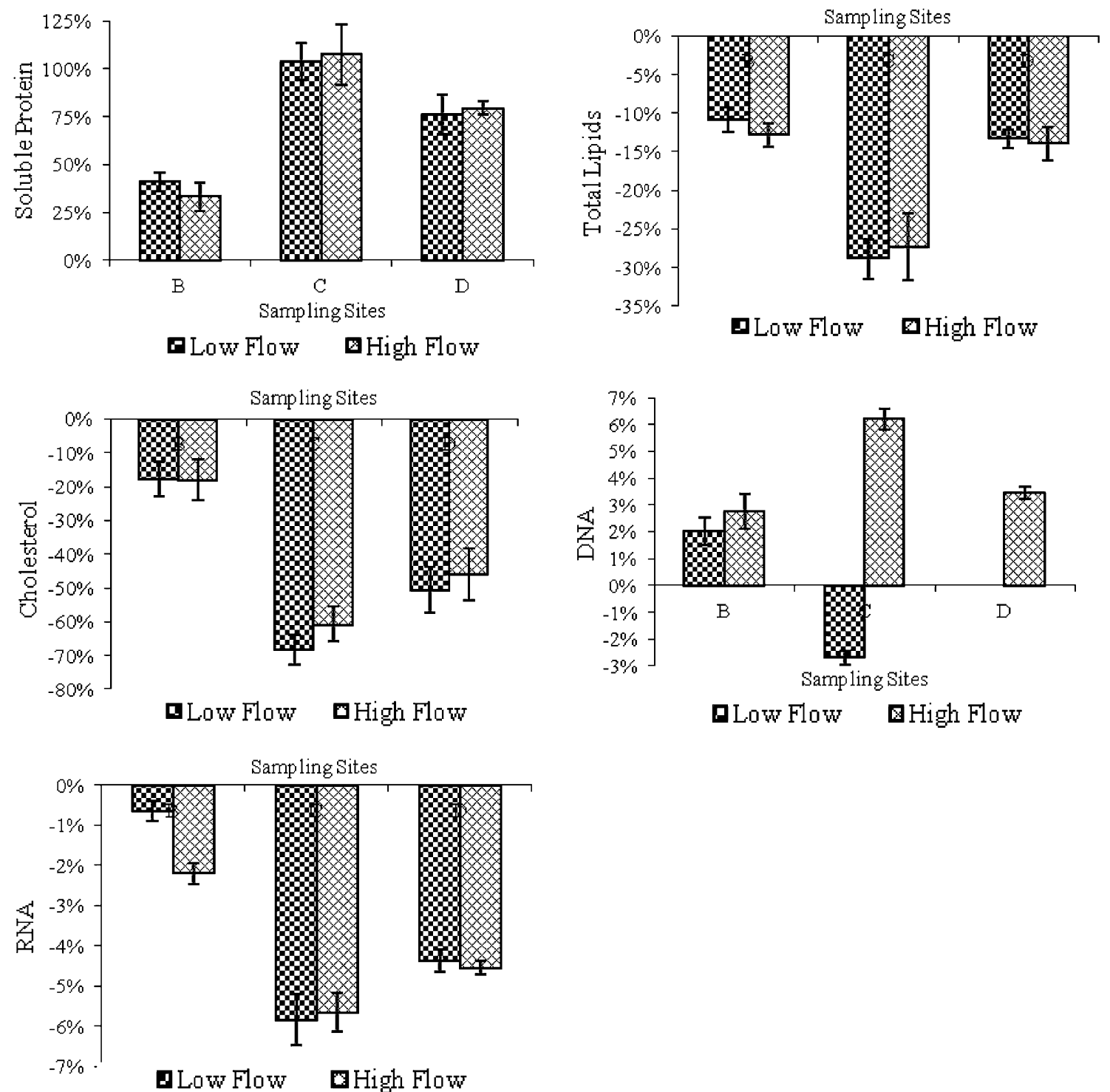

DLow Flow BHigh Flow

Fig. 2 Percent increase $(+)$ or decrease $(-)$ with standard deviation in biochemical profiles of muscles of Cirrhinus mrigala representing different downstream polluted sites; B (Shahdara); C (Sunder); and D (Balloki) as compared with less polluted reference $\boldsymbol{A}$ (Siphon) during the low- and high-flow seasons 
from 17.7 to $68.3 \%$ and from 17.9 to $60.7 \%$ and RNA from 0.65 to $5.83 \%$ and from 2.2 to $5.7 \%$ during low- and high-flow seasons, respectively, as compared to the respective values at the upstream site A.

\section{Discussion}

Fish muscle biochemical profiles can be used as a stress indicator for biological systems such as aquatic life. Vivid differences in the muscle's biochemical parameters appeared in fish specimens collected from downstream sites receiving heavy insults of sewage and industrial effluents than the fish from the upstream site of the Ravi River before its entry through the Lahore city. Evaluation of three nutrients: carbohydrates, proteins and lipids, is generally considered as indicators of fish health. Variations in these nutrients have been described as indicative of long-term exposure to stressors (Mayer et al. 1992). Biochemical responses can be affected by environmental factors, such as physico-chemical profiles of aquatic medium, season, fish nutritional status, age and health (Lohner et al. 2001).

Carbohydrate contents of the fish muscles decreased retrogressively from the site $\mathrm{B}$ to $\mathrm{C}$. The nutrient decrease was reached at 77.1 and $74.2 \%$ for the site $\mathrm{C}$ during low and high flows than the corresponding values at site A. This clearly demonstrates that during high-flow season, dilution of the urban pollutants was able to mitigate their negative effects. Carbohydrates are considered to be the first degraded molecules under stress condition of different animals. Chemical stress causes depletion of stored carbohydrates (Vijayavel and Balasubramanian 2006). Pollutants' stresses might have induced metabolic changes resulting in the increased utility of stored carbohydrates as an energy source. The present results are in accordance with the findings of Garg et al. (2009), who reported significant reduction in carbohydrate contents in the muscles of Labeo rohita, C. mrigala and Catla catla after their separate exposures to heavy metals. Toxicant stress may induce glycogenolysis possibly by accelerating the activity of glycogen phosphorylase to meet the enhanced energy demands or the toxicant may have an effect on glycogenesis by inhibiting the activity of carbohydrate metabolism (Valarmathi and Azariah 2002). Dhavale and Masurekar (1986) suggested that reduction in the tissues' carbohydrate content may be due to the prevalence of hypoxic condition as in oxygen limitation carbohydrate consumption is enhanced. Reduction in dissolved oxygen at the same sampling sites and flow seasons reported by Shakir et al. (2013) also supports this conclusion that decreases in the carbohydrate contents in fish muscles are reflective of less availability of dissolved oxygen and direct effects of heavy metals and other pollutants on the fish.

Total and soluble protein contents of the fish muscle significantly increased for the downstream polluted sites. Pollutants' stresses appeared to accelerate synthesis of body protein. The present results are in agreement with the study of Lohner et al. (2001) who attributed increase in protein contents in response to the exposure of increasing metal concentrations, to synthesis of proteins required to sequester the metals. Similarly, Susan et al. (2010) noticed an increase in protein content in the muscles of $C$. mrigala being exposed to fenvalerate (synthetic pyrethroids) and suggested that the toxicant stress might have stimulated protein synthesis for enzymic detoxification at the expense of glycogen to meet additional requirement in the synthetic activity of body tissues.

Total lipid contents of the fish muscle decreased downstream resembling the pattern of carbohydrate decline. Liver dysfunction or inhibition of oxidative phosphorylation or metabolization of glycerol for energy demand under stress condition due to the polluted environment might have been the possible causes. Vincent et al. (1996) reported variable decline in lipids contents in Catla catla after an exposure of 20, 25, 30 and $35 \mathrm{mg}$ chromium/L. Similarly, reductions in lipids profile have been reported by Kaur and Saxena (2001) in fish flesh sampled from polluted waters of river Sutluj in Pakistan. Shukla et al. (2002) observed decrease in lipids content of Channa punctatus after 60 days' exposure of cadmium individually and in combination with other metals. Giridhar and Indira (1997) suggested that to overcome the stress, animal tends to mobilize lipids by stimulating the lipase which acts on lipids to break them down to free fatty acids. These fatty acids may undergo $\beta$-oxidation leading to the formation of Acetyl CoA (acetyl-coenzyme A) which enters TCA cycle to make the energy available for metabolic functions. Cholesterol contents also showed similar pattern of decreases in response to pollution at downstream sites. Results of the present study are in accordance with AlKahtani (2011) who reported decline in cholesterol content of muscle of Oreochromis niloticus (tilapia) following exposure to different insecticides. Inhibition of cholesterol biosynthesis in the liver might have 
occured due to lack of cholesterol precursors (acetyl-coenzyme A) as suggested by Ali (1989). Reduced absorption of dietary cholesterol as reported by Kanagaraj et al. (1993) and utilization of fatty deposits instead of glucose for energy purpose as reported by Remia et al. (2008) might have also contributed to the observed deficits of cholesterol content.

The DNA contents of the muscle were not significantly different among the downstream sites and seasons. However, elevations for downstream sampling sites, especially during high-flow season, were apparent as compared to the value obtained for fish muscle sampled from the reference site A. The RNA content differed significantly in different seasons and it decreased for the downstream sites. Similar findings have been reported by Yousafzai and Shakoori (2009) who suggested that DNA seemed to be resistant to the ambient toxicants. Das and Mukherjee (2003) also reported elevated DNA and decreased RNA contents in the muscle of Labeo rohita after their exposure to sub-lethal concentration of cypermethrin.

The results indicated significant increases in soluble and total protein contents in fish muscles being exposed to the potential pollutants from the sewage and industrial effluents as compared to the respective values obtained for the fish sampled from the upstream reference site. Conversely, significant reduction in carbohydrates, total lipids, cholesterol and RNA contents of the pollution exposed fish meat as compared to the respective values of fish muscle from the upstream reference site was evident that the fish health was under strong negative pressure due to the pollutants loads. These results reflect that much attention is needed to regulate water pollution to minimize its impact on fish and ultimately human health.

\section{Conclusions}

This study showed that the fish muscles can be used as a bio-indicator of river water pollution. In fact, the muscle biochemical parameters were able to show fluctuations in response to the changes in different study sites during different water flow periods. It appeared that the urban pollutant loads via untreated effluents of the Lahore city have been exerting drastic negative effects on fish health. However, some of the negative effects appeared to be partly mitigated by a higher river flow at some parts of the city. These observations clearly demonstrate that the fish life has been affected at the river's study segment. Therefore, prompt action is needed to strictly regulate the influx of urban effluents into the Ravi River to safeguard the aquatic and public health. Meanwhile, further studies should be conducted by covering a longer distance along the Ravi River around Lahore city to reveal the impact of other sources of pollutions on different fish species of river Ravi.

Acknowledgement Thanks to the Higher Education Commission (HEC), Pakistan for funding under the "Indigenous Ph.D. 5000 Fellowship program" and "IRSIP" to support the research of the first author at University of the Punjab, Pakistan and Newcastle University, UK, respectively.

Open Access This article is distributed under the terms of the Creative Commons Attribution License which permits any use, distribution, and reproduction in any medium, provided the original author(s) and the source are credited.

\section{References}

Ali SS (1989) Morphological and biochemical hazards caused by some organochlorinated insecticides on blood and liver of rat. Ph.D thesis, Department of Zoology, University of the Punjab, Lahore

Al-Kahtani MA (2011) Effect of an insecticide abamectin on some biochemical characteristics of Tilapia fish (Oreochromis niloticus). Am J Agric Biol Sci 6(1):62-68

Anwar KK, Ali SS, Shakoori AR (2004) Effect of a single dose of permethrin on the biochemical components of developing muscle in chick embryo. Pak J Zool 36:7-12

Bhathar N, Vankhede GN, Dhande RR (2004) Heavy metal induced biochemical alterations in fresh water fish Labeo rohita. J Ecotoxicol Environ Monit 14:350-356

Das BK, Mukherjee SC (2003) Toxicity of cypermethrin in Labeo rohita fingerlings: biochemical, enzymatic and haematological consequences. Comp Biochem Physiol C Toxicol Pharmacol 134:109-121

Dhavale DM, Masurekar VP (1986) Variations in the glucose and glycogen content in the tissue of Scylla serrata (Forskal) under the influence of cadmium toxicity. Geobios 13:139-142

Du Bios M, Gilles KA, Hamilton JK, Robbers PA, Smith F (1956) Colorimetric method for determination of sugars and related substances. Anal Chem 28:350-356 
Garg S, Gupta RK, Jain KL (2009) Sublethal effects of heavy metals on biochemical composition and their recovery in Indian major carps. J Hazard Mat 163:1369-1384

Giridhar P, Indira P (1997) Effects of an organophosphorus nuvan on total lipids and lipase activity of the fresh water fish Labeo rohita (Ham.). Indian J Comp Anim Physiol 15:37-40

Henry RJ (1964) Clinical chemistry: principles and techniques. Harper \& Row, New York

Henry RJ, Henry M (1974) Clinical chemistry, principles and techniques, 2nd edn. Harper \& Row Publishers, New York, pp 1440-1443

Jacobson-Kram D, Keller KA (2001) Toxicology testing handbook. Principles, applications and the data interpretation. Marcel Dekker, New York

Kanagaraj MK, Ramesh M, Sivakumari M, Manavalaramanujam (1993) Impact of acid pollution on the serum haemolymph cholesterol of the crab, Paratelphusa hydrodromous. J Ecotoxicol Environ Monit 3:99-102

Kaur T, Saxena PK (2001) Impact of pollution on the flesh of some fishes inhabiting river Satluj waters-a biochemical study. Indian J Environ Health 44(1):58-64

Lohner TW, Reash RJ, Williams M (2001) Assessment of tolerant sunfish populations (Lepomis sp.) inhabiting selenium-laden coal ash effluents. 2. Tissue biochemistry evolution. Ecotoxicol Environ Safe 50:217-224

Lowry OH, Rosebrough NJ, Farr AL, Randall RJ (1951) Protein measurement with the Folin phenol reagent. J Biol Chem 193:265-275

Mayer FL, Versteeg DJ, Mckee MJ, Folmar LC, Graney RL, Mccume DC, Rattner BA (1992) Physiological and nonspecific biomarkers. In: Hugget RJ, Kimerle RA, Mehrle PM Jr, Bergman HL (eds) Biomarker, biochemical, physiological and histological markers of anthropogenic stress. Lewis Ann, Arbor, pp 5-85

Remia KM, Logaswamy S, Logankumar K, Rajmohan D (2008) Effect of an insecticides (Monocrotophos) on some biochemical constituents of the fish Tilapia mossambica. Pollut Res 27:523-526

Saeed MM, Bahzad A (2006) Simulation of contaminant transport to mitigate environmental effects of wastewater in river Ravi. Pak J Water Resour 10(2):43-52

Safahieh A, Hedayati A, Savari A, Marammazi JG (2010) Effect of experimental exposure to mercury chloride on phosphatase enzymes in Yellowfin sea bream. Am Eur J Toxicol Sci 2(3):162-168

Schneider WC (1957) Determination of nucleic acids in tissues by pentose analysis. In: Colowick SP, Kaplan NO (eds) Methods in enzymology. Academic Press, New York, pp 680-684

Shakir HA, Qazi JI (2013) Impact of industrial and municipal discharges on growth coefficient and condition factor of major carps from Lahore stretch of Ravi. J Anim Plant Sci 23(1):167-173

Shakir HA, Chaudhry AS, Qazi JI (2013) Impact of anthropogenic activities on physico-chemical parameters of water and mineral uptake in Catla catla from river Ravi, Pakistan. Environ Monit Assess 185:2842-3833

Shakoori AR, Ahmed MS (1973) Studies on the liver of chickens, I. Liver growth and nucleic acid contents. Pak J Zool 5:111-117

Shukla V, Rathi R, Shastry KV (2002) Effect of cadmium individually and in combination with other metals on the nutritive value of fresh water fish Channa punctatus. J Environ Biol 23(2):105-110

Susan TA, Sobha K, Veeraiah K, Tilak KS (2010) Studies on biochemical changes in the tissues of Labeo rohita and Cirrhinus mrigala exposed to fenvalerate technical grade. J Toxicol Environ Health Sci 2(5):53-62

Valarmathi S, Azariah J (2002) Impact of two sublethal concentrations of copper chloride and chlorine on the excretory products of crab Sesarma quadratum (Fabricicus). Turk J Zool 26:357-361

Vijayavel K, Balasubramanian MP (2006) Fluctuations of biochemical constituents and marker enzymes as a consequence of naphthalene toxicity in edible estuarine crab, Scylla serrata. Ecotoxicol Environ Saf 63:141-147

Vincent S, Cyril AKL, Ambrose T (1996) Impact of heavy metal chromium on bioenergetics of the Indian major carp Catla catla (Ham.). Pollut Res 15(3):273-275

Wilson RW, Taylor EW (1993) The physiological responses of freshwater rainbow trout, Oncorhynchus mykiss, during acutely lethal copper exposure. J Comp Physiol 163(B):38-47

Yousafzai AM, Shakoori AR (2009) Fish white muscle as biomarker for riverine pollution. Pak J Zool 41(3):179-188 